\title{
Teaching Problem-solving Skills through Learner Autonomy based Learning and Local Wisdom Insight
}

\author{
Abdul Salam M \\ Department of Physics Education \\ Faculty of Teaching and Education Science \\ Universitas Lambung Mangkurat \\ Banjarmasin, Indonesia \\ salam@unlam.ac.id
}

\author{
Sarah Miriam, Misbah \\ Department of Physics Education \\ Faculty of Teaching and Education Science \\ Universitas Lambung Mangkurat \\ Banjarmasin, Indonesia
}

\begin{abstract}
- $21^{\text {st }}$-century skills mastery and cultural transformation process are two things that should be concerned with education world nowadays. The next generation of this nation not only should be smart intellectually but also respectful of the cultural values of society and conserve them. Therefore, the instructional path in one unit of education should give the synergy of both $21^{\text {st }}$-century skills and cultural transformation process. One of the efforts done by the researcher team is teaching problem-solving skills to the college students through learner autonomy based learning and local wisdom insight. The research was conducted in physics education study program Faculty of Teacher Training and Education, Universitas Lambung Mangkurat in 2017. The result showed that the use of learner autonomy based learning and local wisdom insight could train the problem-solving skills at the Bloom's taxonomy level of analyzing, evaluating, and creating.
\end{abstract}

Keywords—problem-solving, autonomy, local wisdom

\section{INTRODUCTION}

The globalization era that marked the development of science and technology, as well as the free market, has caused the mixing in all aspect of life, including in the aspect of habit or culture. The high mobility seems to cause such a missing territorial line between countries. With this condition, there is a possibility that Indonesian culture which tends to very eastern could be gone swallowed by time.

Facing such condition, at least there are two efforts that imperative to do. Firstly, prepare such qualified and competitive human resources who understand what knowledge and skill needed. Therefore, the mastery of 21-century skills becomes a certain skill that should be trained in the education world. We hope that this nation not only become the watcher in the future, nor consuming minded. More than that, we are expected to be the agent of change. Secondly, do culture transformation especially for the local culture. According to [1] the culture existence owned by the Indonesian nation is tools to build the character of the nation. The efforts to conserve the national culture should always be the concern of the nation.
Based on the explanation above, the researcher team has designed an instructional that is expected could train one of the $21^{\text {st }}$-century skills, that is the problem-solving skill which has a local wisdom-insight. The instruction is designed in the setting of learner autonomy based learning. Autonomy according to Holec [2] is

"....the ability to take charge of one's own learning'. To take charge of one's own learning is to have, and to hold, the responsibility for all the decisions concerning all aspects of this learning: determining the objectives; defining the contents and progressions; selecting methods and techniques to be used; monitoring the procedures of acquisition ...; and evaluating what has been acquired".

In the implementation, learning autonomy is not automatically given directly and completely, but it is adjusted according to the level of student's actual capability. In short, the level of autonomy is divided into three stages [3]. To beginner learners, generally, they have to get through the first stage of autonomy level. The instructional model implemented at every level of autonomy is also differed depending on the learning material characteristic and learner's ability. The type of instructional model used depends on how big is the responsibility will be given to students in order to manage the learning on their own.

Learner autonomy based learning together with local wisdom insight was set to train students' problem-solving skill at the cognitive level of applying, analyzing, and creating. Especially for the creating level, students were expected to apply science process skills in designing physics experiment to solve academic problems given. In addition, students will be informed about South Kalimantan local wisdom insight of the diamond in Martapura or it is called "Intan Martapura" by connecting its special nature with perfect reflection discussed in the learning topic "Geometric Optic".

\section{Research Method}

Type of the research is a developmental research which produces a set of instructional material that based on learner 
autonomy and supported by local wisdom insight. The research product is the learning material, lesson plan, student worksheet, and formative evaluation of instruction. The instructional developmental model used was according to Dick \& Carrey model in which the phases comprise of (1) identify instructional goal(s), (2) conduct instructional analysis, (3) analyze learner and context, (4) write performance objectives, (5) develop assessment instruments, (6) develop instructional strategy, (7) develop and select instructional materials, and (8) design and conduct formative evaluation of instruction.

The phases of instructional materials development and implementation were conducted at Universitas Lambung Mangkurat Banjarmasin. The research was conducted from March to October 2017. The subjects of the instructional materials trial were the second-semester students at the academic year of 2016/2017 of Physics Education Study Program who had programmed Basic Physics II course.

The data were collected by test and non-test techniques. The test was used to measure the problem-solving skills by using some observation sheets and written test of students' study result. The data were stated in the form of proportion of every skill item given. Furthermore, the non-test technique was used to measure students' responses as interest and motivation in following the instruction. Students' responses were stated as the mean score for all measured items. In this case, the researcher used respond questionnaire of ARCS developed by Keller in 1989. And then, the mean score of every aspect of students' responses was categorized according to table 1 .

TABLE 1. CATEGORY FOR STUDENTS RESPOND

\begin{tabular}{cc}
\hline Score Interval & Category \\
\hline$\geq 4,21$ & Very good \\
$3,41-4,20$ & Good \\
$2,61-3,40$ & Adequate \\
$1,81-2,60$ & Less good \\
$\leq 1,80$ & Poor \\
\hline
\end{tabular}

\section{RESUlT AND DiSCUSSION}

Learner autonomy based instructional is an instructional strategy that designed to give a responsibility to students so that they can study independently. The responsibility task is certainly given based on student's readiness of knowledge and skill. The other important aspects to be considered are the task structure and the clearness of the activities in class so that the curriculum target still can be achieved.

In this study, the students were trained to solve physics problems starting from the cognitive level of Applying, to Analyzing, Evaluating, and Creating. Applying Direct Instruction Model, the first lesson focused on modeling step by step solving physics problems at each level mentioned. Especially for the creating level, the students were trained to design an experiment to solve the academic problem given. Along with the development of students' learning experience, teacher's direct explanation was getting less and less delivered. Students were given more times to solve academic problems designed in the student's worksheet. The change in the level of instructional responsibility was followed by the change in the model of instructional applied, which become more student-centered. In this study, Inquiry Model of Instruction was applied in the second lesson, while Group Investigation type of Cooperative Learning Model was in the third lesson.

The topic of Reflection of Light which was taught at the first lesson was linked with the local wisdom of South Kalimantan, "Intan Martapura". The diamond has its unique for its glow. This unique is because of when the light gets into the diamond, most part of it will be perfectly reflected few times by the inner surface of the diamond. A perfect reflection of the light when it tries to get out of the diamond is easy to happen because the diamond has a refraction index of 2.417 so that the critical angle is just 24 degrees.

\section{A. Problem-solving Skills}

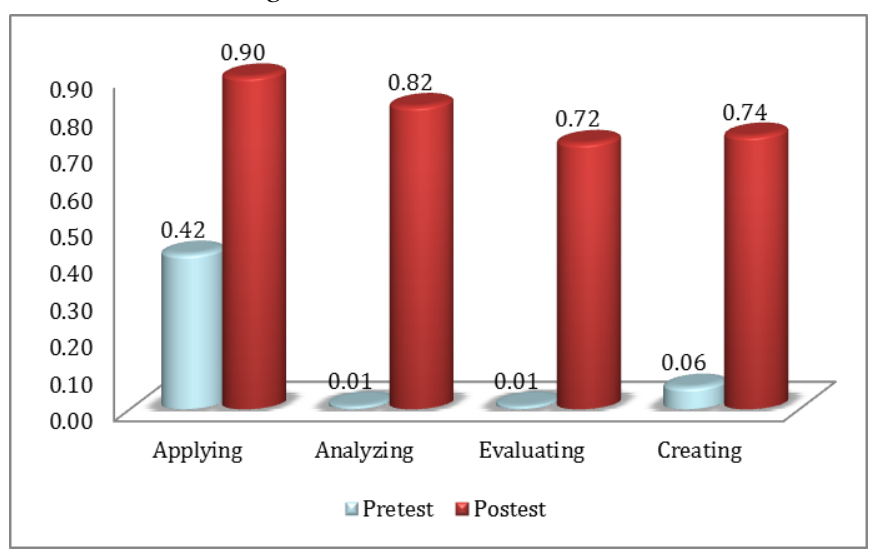

Fig 1. Achievement of Student's Problem-solving Skills

Picture 1 shows that students' problem-solving skills for each cognitive level have improved after the implementation of the teaching materials developed. Students' skill at the level of applying has achieved the proportion of 0.42. At this level, students were asked to draw the construction of image on lens, calculate the distance and height of the image, and also the characteristics of the image created. This skill has been trained to students since they were in junior high school (SMP). For the level of higher education students, this skill is also trained, but the problems given are more complex. This skill has improved to 0.90 after implementing the lessons.

Analyzing skill that trained in this study is to make the modeling of reflected and refracted rays in drawings. By geometrical approach, the drawings were analyzed to formulate Snellius' law and Gauss equation. The procedural skill is still new to the students so no wonder that the students' proportion of pretest for this level was only 0.01 . However, after implementing the lessons, the proportion of this skill has improved to 0.82 . The same case occurred with the evaluating skill which evaluates the uses of reflection and refraction concepts in technology products as well as explaining daily 
phenomenon linked. At this evaluating level, students' achievement has improved from 0.01 to 0.72 .

At the level of creating, students were trained to solve an academic problem, which is designing an experiment activity by applying science process skills. Through learner autonomy based learning, the proportion of students' skill at this level has improved from 0.06 at pretest to 0.74 at posttest. Along the learning process, the science process skills were trained completely, which are (1) formulating the objectives, (2) formulating hypotheses, (3) identifying variables, (4) defining variables operationally, (5) identifying tools and material, (6) making work procedures, (7) implementing the experiment procedure, (8) analyzing and discussing data, and (9) making conclusion. Because of the limitation of time and also the test technique applied on the evaluation phase, only components in point one to six of the science process skills can be measured as learning achievement as showed in Figure 2.

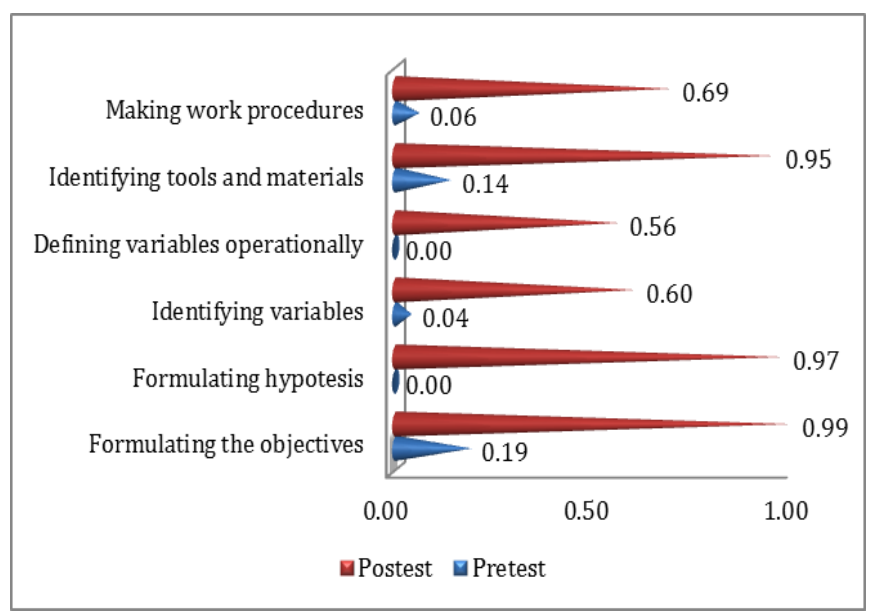

Fig 2. Achievement of Student's Science Process Skills

As can be seen in picture 2, the proportion of each science process skills has significantly improved. The lowest proportion is on the skill of defining variables operationally which only as big as 0.56 . The researchers found that some students have not defined the experiment variables operationally yet. Some of those students tend to define the variables conceptually based on physics theory. Some other students gave an incomplete definition of those variables asked. A good operational definition is one that gives complete information on what variable that is, how it can be measured, manipulated, and conditioned, and also how it should be stated.

Another science process skill that is also still low in proportion is identifying the variable. Most of the students give inadequate number of the control variables in the experiment designed. Generally, they only stated one type of control variable, while there were more factors that are potential in affecting the measurement results, but they were constant in the running of the experiment. The reason of the lowness proportion of making the working procedure skill mostly caused by the working procedure was not completed by the observation table, picture/equipment arrangement, or because of the use of the unsystematically sentence.
In general, the learner autonomy based learning developed is able to be used to train problem-solving skills including the science process skills in the geometric optic topic. This finding is in line with the previous research by [4] which revealed that learner autonomy based learning on the dynamic electric topic is able to increased students science process skill.

\section{B. Students Respond to the Learning}

Students' respond data to the learning comprise of assessment on teaching materials and the implementation are as shown in Figure 3.

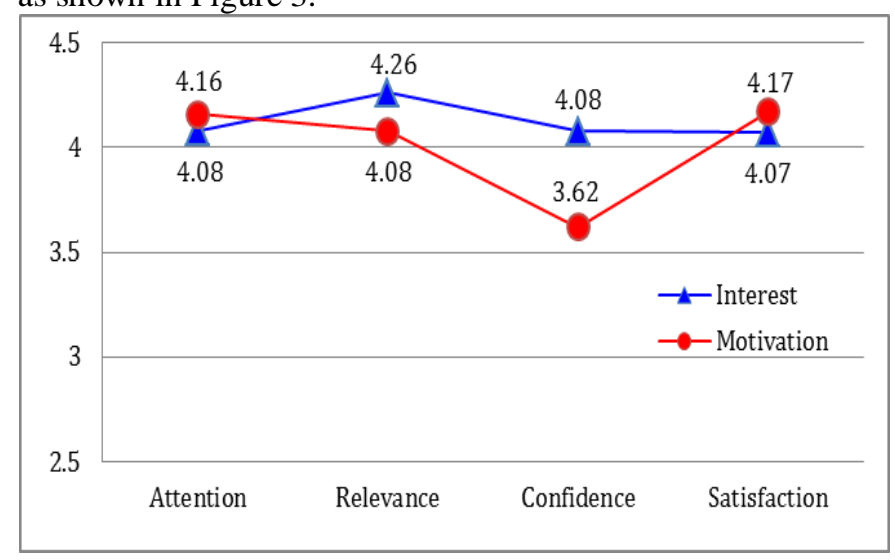

Fig 3. Students' respond on the learning

According to picture 3, the teaching materials based on learner autonomy and local wisdom insight receiving a good respond from the students. The whole aspects of interest and motivation which comprise of attention, relevance, confidence, and satisfaction were in the good category because they have mean scores above 3.41. Even for the aspect of relevance of interest was in very good category (above 4.21), the relatively low mean score was on the aspect of self confidence. According to [5], self-confidence aspect of students has a strong relationship with a positive expectation to achieve success. The level of the self-confidence is in correlation with motivation and efforts to achieve goals. The instructional designed should give an opportunity to students to predict their success opportunities. Another effort that should be concerned is giving positive reinforcement to students through feedback which is relevant and given at the right time. In short, strategies to build self-confidence is proposed by [5] in part is related to Performance Requirements, Success Opportunities, and Personal Control [6].

\section{CONCLUSION}

Based on the data of the study result and discussion, it can be concluded that the learner autonomy based learning that support by local wisdom insight is able to train problemsolving skill to students. 


\section{REFERENCES}

[1] R. Yunus, "Transformasi Nilai-Nilai Budaya Lokal Sebagai Upaya Pembangunan Karakter Bangsa", Jurnal Penelitian Pendidikan, 13 (1), 2013, pp 67-79

[2] D. Dafei, "An Exploration of the Relationship Between Learne Autonomy and English Proficiency", The Asian EFL Journal, 24, 2007, pp 1-23.

[3] M. Salam M., A. Prabowo, and ZAI Supardi, "Pengembangan perangkat perkuliahan inovatif berdasarkan tingkat otonomi pebelajar pada perkuliahan Fisika Dasar", Jurnal Penelitian Pendidikan Sains, 4 (2), 2015, pp 547-556.

[4] M. Salam, and S. Miriam, "Pembelajaran Berbasis Learner Autonomy untuk Melatihkan Keterampilan Proses Sains”, Jurnal Sains dan Pendidikan Fisika (JSPF), 12(3), 2016, pp 233-239.

[5] J.M., Keller, "First Principles of Motivation to learn and $\mathrm{e}^{3}$-learning", Distance Education, 29(2), 2008, pp 178-185.

[6] S. Malik, "Effectiveness of ARCS Model of Motivational Design to Overcome non Completion Rate Rate of Students in Distance Education", Turkish Online Journal of Distance Education (TOJDE), 15 (2), 2014, pp 194-200. 